\title{
Trends in the development of the EU natural gas market and digitalization of the gas industry
}

\author{
Mikhail Ulchenko \\ Luzin Institute for Economic Studies - Subdivision \\ of the Federal Research Centre «Kola Science \\ Centre of the Russian Academy of Sciences», \\ Apatity, Russian Federation \\ https://orcid.org/0000-0002-5227-1772
}

\begin{abstract}
With its impressive production capacity, the EU countries consume a huge amount of energy, $25 \%$ of which is generated by natural gas (450-480 billion $\left.\mathrm{m}^{3}\right)$. At the same time, the demand for gas in the $\mathrm{EU}$ continues to grow due to low prices, the growth of energy intensity of residential heating, and the recovery of economic growth in a number of countries. To determine the trends in the gas market, the article reviews the factors that influence the internal gas consumption of the European Union. It was revealed that due to the depletion of its own resources, as well as a decrease in gas production at the largest in Europe field "Groningen", the volume of domestic gas production, in the period from 2001 to 2018, decreased by 2 times. The paper defines the share of Russian gas in the $\mathrm{EU}$ market, which amounted to more than $34 \%$ and the objective prerequisites for its increase in the next 2-3 years. The study concluded that the forecasts of experts on a significant increase in the volume of supplies of American liquefied natural gas to the EU countries have not been confirmed. At the same time, the share of Russian LNG, after the successful launch of the Yamal LNG project, is constantly growing. In addition, in the current context of the struggle for markets, digitalization of the gas industry is seen as an opportunity to improve the efficiency of management and operation of technological systems, which should help to reduce costs, and ideally prices for end users.
\end{abstract}

Keywords - natural gas, liquefied natural gas, export, import, Russian Federation, European Union

\section{INTRODUCTION}

Despite a significant reduction in domestic energy consumption, dependence on energy imports from the European Union is increasing. In 1990, the EU imported just over $50 \%$ of energy resources from the total consumption, primarily oil and gas, but in 2015-2017, this figure exceeded $70 \%$.

Being the "cleanest" of all existing hydrocarbon fuels, natural gas is expected to remain the most popular $[1,2]$. That is why the countries of the European Union implementing the strategy "20-20-20", according to which, by 2020 within the Union it is planned to reduce energy consumption and carbon dioxide emissions by $20 \%$ (compared to 2000), and increase the amount of energy obtained from renewable sources [3], continue to actively import this type of hydrocarbon fuel. The situation is complicated by the fact that in the period from 2010 to 2018 , the volume of gas production in the EU has decreased significantly.

Given the growing needs of the countries of the European Union's natural gas, as well as the lack of a unified position on the question of increasing the purchases of Russian fuel, the aim is to determine the status of the gas industry and the identification of factors that may influence its development in the short term.

\section{MATERIALS AND METHODS}

To achieve the objectives of the study, the methods of economic-statistical and system analysis were used. Also, an important role is given to expert and expert mathematical methods. It is through the use of these methods that the scientific nature of the study is ensured. The information base for the study was the publication of foreign and domestic experts, official statistics obtained from the Federal state statistics service - Rosstat, Eurostat, as well as official bulletins of British Petroleum and Norwegian Petroleum Director, for the period from 2000 to 2018.

\section{RESULTS}

Over the past 9 years, the maximum gas consumption in the EU countries was observed in 2010. However, since 2011, the demand for gas decreased, as a result, in 2014 consumption amounted to 415 billion $\mathrm{m}^{3}$, which is almost 19\% (95 billion $\mathrm{m}^{3}$ ) less than in 2010. 2015, 2016 and 2017 were marked by a significant increase in gas consumption, from 415 billion $\mathrm{m}^{3}$ in 2014 to 491 billion $\mathrm{m}^{3}$ in 2017 , due to the refusal of local thermal power plants from coal in favor of gas, as well as severe winter periods. Figure 1 presents data on the volume of natural gas consumption in the European Union from 2010 to 2018 [3, 4].

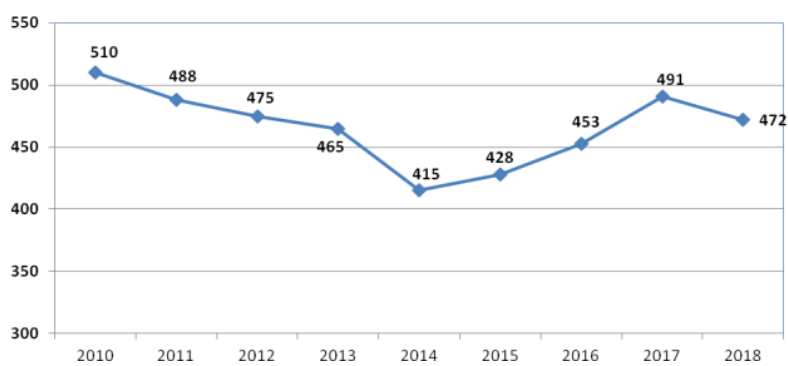

Fig 1. Natural gas consumption by EU countries, billion m3

In recent years, the volume of gas production in the EU is significantly reduced, for several reasons. First, the depletion of deposits and the fall in oil prices (and, as a consequence, gas). Secondly, the increase in the costs of mining companies, including due to the strengthening of environmental legislation, as well as the desire to improve the long-term efficiency of field development through the implementation of capital-intensive "digital" projects. Third, 
the planned decline in production at the largest field in the EU - "Groningen" (Netherlands), which provided more than $10 \%$ of the total consumption of natural gas in Europe. This led to the emergence of a number of earthquakes, which caused damage to roads, houses and other types of real estate. The reduction of gas production at the "Groningen" field forces European consumers to shift to external suppliers $[5,6]$.

In the UK, there is a long-term trend of falling gas production, which, since 2000 , has decreased by almost three times. With the current rate of decline by 2020 , the country will produce no more than $25-28$ billion $\mathrm{m}^{3}$ of gas. Another important fact is that about $75 \%$ of the UK's gas fields belong to Scotland, which may complicate their development due to a number of internal political factors.

One of the main options for increasing gas production in the EU, at present, is the development of shale gas fields, mainly located in Germany. However, political forces and public movements strongly against the application of the technology of "fracking" (hydraulic fracturing) needed to implement the extraction of gas in shale rocks. In this regard, there is no accurate data on the volume of proven or proven shale gas reserves in Germany.

The volume of gas production in the EU, at the end of 2017 and 2018, amounted to a little more than 120 billion $\mathrm{m}^{3}$, the remaining volume, which is about 370 billion $\mathrm{m}^{3}$ was imported. The main gas suppliers to the EU are Norway and Russia. Algeria, which until recently was considered one of the largest gas suppliers, has reduced its share in the European market in recent years. Nevertheless, the tripartite agreements concluded between the state Algerian company "Sonatrach", the French "Total" and the Spanish company "Repsol" on the joint development of a number of fields, including "Timimoun", "Tin Fouye Tabnkoft" and "Reggane Nord", indicate that by 2020 Algeria will be able to increase the volume of natural gas production by $8-10$ billion $\mathrm{m}^{3}[7$, 8]. According to experts, about half of this volume the Algerian side will be able to export to the EU countries Spain, Italy and France.

The total volume of gas supplied by Russia and Norway is more than $50 \%$ of EU consumption. The main exporter of gas and oil in the Norway is the state company "EQUINOR" (until may 2018 was called "STATOIL").

In 2016, the Norwegian authorities decided to increase gas production by ten percent from 30 to 33 billion $\mathrm{m}^{3}$ at the largest field in Norway - "Troll". This volume of production is comparable in size to the annual gas consumption of France. The increase in production, in theory, could allow Norway to oust Russia in the European gas market. However, in practice, it is more correct to say that the conditional "partnership" of the two countries in the field of aggressive pricing policy will contribute to the nonadmission or "restriction" of LNG supplies to the European market from the US [9].

Table 1 presents data on the total volume of natural gas exported by Russia in the period from 2000 to 2018 [4, 10]
TABLE I. THE VOLUME OF RUSSIAN EXPORTS OF NATURAL GAS VIA PIPELINES IN 2000 - 2018

\begin{tabular}{|c|c|c|}
\hline Years & To EU countries (billion $\mathbf{~}^{\mathbf{3}}$ ) & Total (billion $\mathbf{~}^{\mathbf{3}}$ ) \\
\hline 2000 & & 192,9 \\
\hline 2005 & & 209,2 \\
\hline 2010 & 137,8 & 177,8 \\
\hline 2011 & & 189,7 \\
\hline 2012 & & 178,7 \\
\hline 2013 & 137,2 & 196,4 \\
\hline 2014 & 121,2 & 174,3 \\
\hline 2015 & 132,1 & 185,5 \\
\hline 2016 & 151,3 & 198,9 \\
\hline 2017 & 155,9 & 210,2 \\
\hline 2018 & 164,9 & 220,6 \\
\hline
\end{tabular}

Today, Russia remains the largest supplier of gas to the EU, despite sanctions from European countries and the response of the Russian government. Moreover, according to the results of 2017 and 2018, "Gazprom" delivered 155.9 billion and a record 164.9 billion $\mathrm{m}^{3}$ of gas, respectively, which is more than $34 \%$ of the EU gas market [10].

According to Deputy Minister of energy of the Russian Federation - Anatoly Yanovsky, despite the decline in natural gas consumption in the EU, in 2018 by 19 billion $\mathrm{m}^{3}$, the volume of Russian gas exports to these countries increased.

The reasons why EU countries import a large amount of natural gas, even with a decrease in its consumption, according to the results of last year, are several:

- first, as already mentioned, this is a significant reduction in the volume of domestic gas production;

- secondly, the increase in the volume of natural gas purchases by Ukraine, which for political reasons, buys it not directly from Russia, and the reverse of the European Union.

Perhaps the situation will change in the near future, as it became known, at the last in June 2019, the St. Petersburg international economic form, the Ukrainian side, the head of PJSC "Gazprom" Alexei Miller made an offer to buy Russian gas directly. It was about the fact that the price of gas for Ukraine will be $25 \%$ lower, the one at which the Ukrainian side buys reverse gas from Europe now [11].

To transport Russian natural gas to the EU countries, a special Northern corridor has been created, including the "Bovanenkovo-Ukhta", "Bovanenkovo-Ukhta - 2", "UkhtaTorzhok", "Ukhta-Torzhok - 2", "Gryazovets-Ust-Luga", "Gryazovets-Vyborg", "Nord stream" and "Nord stream - 2" gas pipelines. With the help of these pipelines, the needs for natural gas are met not only in the EU countries, but also in the North-West of Russia [12-15]. Construction of the "Nord stream - 2" gas pipeline, despite the difficulties, continues, and as of mid-June 2019, it was completed by $60 \%$. The main reason for the delay in construction is the lack of permission from Denmark to lay a gas pipeline in its territorial waters. As Copenhagen is hindering the 
implementation of this project, the operator is considering the possibility of changing the route of laying the pipeline, bypassing the territorial waters and the special economic zone of Denmark. It is important to understand that according to the UN Convention on the law of the sea, Denmark cannot prevent the flight of aircraft, passage of ships, laying cables and pipelines in its economic zone.

The planned capacity of the Northern corridor, in the near future, is limited to 110 billion $\mathrm{m}^{3}$, this is clearly not enough in the face of increased demand for natural gas from the EU [16]. The situation is complicated by the fact that in the context of the Ukrainian geopolitical crisis, PJSC "Gazprom", despite all attempts, does not see Ukraine as a reliable partner, and is considering the option that after the end of contractual obligations (the end of 2019), it will be necessary to limit the transit of Russian gas to the minimum possible volumes. In the circumstances, when the project "South stream" under pressure from the European Commission was canceled, and the project "Turkish stream" has not yet been implemented until the end (there is an active phase of construction), it is necessary to take into account that: first, the demand for natural gas in the EU is growing; secondly, despite statements about the desire to reduce dependence on Russian energy resources, the European Union countries prefer to buy Russian gas, which is much cheaper than American liquefied natural gas (LNG), despite a number of forecasts $[17,18]$. In the current situation, one of the promising options for Russia is the use of a marine method of natural gas transportation.

By mid-2019, Russia has successfully implemented two megaprojects for the production of liquefied natural gas "Sakhalin - 2" and "Yamal - LNG". The capacity of the first project is more than 10.5 million tons, the second - 16.5 million tons, with a planned increase to 17.4 million tons by the end of the year. If all of the gas in the framework of the project "Sakhalin - 2", sold in the markets of the AsiaPacific region, the gas obtained in the framework of the project "Yamal - LNG" is implemented and on the EU market.

Despite the fact that the share of Russian liquefied natural gas in the market of the European Union is not so large, by the end of February 2019, Russia ranked first in LNG supplies to Europe - 1.41 million tons, ahead of Qatar - 1.33 million tons, Algeria, Nigeria and the United States - 0.64 million tons. At the same time, it should be understood that the same PJSC "Novatek" plans to build three lines of a liquefied natural gas plant with a total capacity of 19.8 million tons by 2025, within the framework of the "Arctic LNG - 2" project. This will significantly increase the share of Russian liquefied natural gas in the world market $[10,11]$.

An important feature of Russian LNG in the EU market is its price, which is $10 \%-15 \%$ lower than the us, while within the framework of the "Arctic LNG - 2" project it is planned to use domestic equipment for liquefying gas, which will reduce the cost by another $20-25 \%$.

The use of digital technologies is an effective solution to reduce costs in the production and transportation of natural gas. Digitalization is not an automation of processes, but an opportunity to improve the efficiency of technological systems and their management. In fact, it is a specialized system of continuous monitoring of the condition of the equipment, allowing predicting the periods of its maintenance, thereby preventing possible downtime. As a result, fewer personnel are required, which is especially important when it comes to working on a remote well, offshore platform or servicing a remote section of a gas pipeline.

One of the main competitors of Algeria, Norway and the Russian Federation in the gas market of the European Union are the United States. It's no secret that 20 years ago the United States was the largest importer of natural gas in the world, but the development of "fracking" technology, which allows the extraction of gas and oil shale rocks, changed the balance of power in the global gas market. At first, the US was able to meet domestic demand for gas, and then made a loud statement that it was entering foreign markets. The primary goal was the market of the EU countries, but serious competition from Russia, Norway, Algeria and Qatar forced the US to reorient itself to the market of the Asia-Pacific region.

The volume of us LNG supplies to the EU countries is growing annually, so if in 2016 the US exported only 510 million $\mathrm{m}^{3}$ of gas, then by the end of $2018-2.7$ billion $\mathrm{m}^{3}$. At the same time, it should be noted that the growth of supplies, compared with 2017, amounted to only 0.6 billion $\mathrm{m}^{3}$. However, more than $50 \%$ of the us gas imported by EU countries was purchased in the last 3 months of 2018. This trend is explained by the decline in gas prices in the AsiaPacific region, where the United States carries out the main LNG supplies and their reorientation to the European market.

LNG production in the United States has a number of features. The main feature is that the gas used for liquefaction and export comes directly from the gas transportation system, which is integrated with the gas transportation systems of Canada and Mexico. This fact is an undeniable advantage, as it creates prerequisites for increasing the volume of supplies. Also positive aspects include the fact that export - oriented companies buy gas intended for liquefaction and resale at domestic prices.

Another feature of the production of liquefied natural gas in the United States is that, on the one hand, American LNG reduces world gas prices, on the other, provokes their growth within the country, due to increased demand.

By mid-2019, 6 plants with a total capacity of more than 65 million tons of LNG per year - "Cameron LNG", "Corpus Christi LNG", "Cove Point LNG", "Elba Island LNG", "Freeport LNG" and "Sabine Pass LNG"-are operating or are in the final stage of completion in the US.

Despite the fact that 5 years ago, due to the fall in oil and gas prices in the US, 20 large LNG projects with a total capacity of more than 170 million tons were frozen, several more projects are currently under deep development "Calcasieu Pass LNG", "Delfin FLNG", "Golden Pass", "Magnolia LNG" and several others. The probability of implementation of these projects is quite high, this is due to the fact that some of them have already discussed the signing of contracts with buyers. In addition, American companies refused the condition of "destination clauses", according to which importers had no right to resell gas in other markets. 


\section{DISCUSSION}

Today, there is a situation when the volume of gas consumption in the EU countries in the period from 2014 to 2018 increased by $17 \%$ (the maximum value in 2017 is 494 billion $\mathrm{m}^{3}$ ), and the volume of own production significantly decreased (to 120 billion $\mathrm{m}^{3}$ ), and according to most experts, will be reduced to 100 and less than billion $\mathrm{m}^{3}$ by 2022 . At the same time, gas consumption in the EU countries, according to the authors of the article will range from 450 to 500 billion $\mathrm{m}^{3}$. This is due to the recovery of the economies of individual countries, as well as the refusal of many thermal power plants from coal in favor of gas.

We also emphasize that the growth in demand for gas in 2016, 2017 and 2018 was noted in those countries that have long declared the refusal or minimization of the use of fossil fuels in favor of alternative energy sources. So if the increased demand for gas in the Netherlands by $90 \%$, and $56 \%$ in the UK can be explained by a decrease in its own gas production, as mentioned above, the increase in imports of Russian gas by Denmark, in 2017, by more than $150 \%$ was unpredictable.

In addition to Algeria, Norway, Qatar, the United States and the Russian Federation, a number of other potential suppliers - Azerbaijan, Iran-are actively trying to successfully sell their raw materials on the EU market.

Azerbaijan has contracts for the supply of natural gas to Europe and Turkey, within the framework of the southern gas corridor project for 6 and 10 billion $\mathrm{m}^{3}$ of gas, respectively. Most of the gas intended for export is produced at The largest Shah Deniz field. At the same time, the volume of production at the field, at the end of 2018 , decreased by $3.5 \%$. As a result, Azerbaijan, for the first time since 2006, resumed the purchase of natural gas from Russia to meet its domestic needs. This may indicate either that difficulties have been encountered in the development of the field or that an error has been made in the initial calculations. In any case, at this stage Baku has no real opportunities to increase the volume of natural gas supplies to the European Union.

Iran, having significant proven reserves of natural gas more than 34 trillion $\mathrm{m}^{3}$, has not become a significant player in the global energy market. The annual volume of production in the country is at the level of 230-250 billion $\mathrm{m}^{3}$, while only $4-5 \%$ is exported. Among the main reasons hindering the export of Iranian gas are the following:

- first, underdevelopment of the transmission infrastructure and production capacity;

- secondly, the country is under constant sanctions, which prevents investors - large foreign companies to participate in the development of large deposits;

- thirdly, it is a constant growth of domestic demand for natural gas.

Given these factors, it is safe to say that in the near future, Iran will not be able to conclude a mutually beneficial energy Union with the EU.

\section{CONCLUSIONS}

Based on the above, we can draw a number of conclusions:
- in 2015-2018, the volume of gas production in the EU significantly decreased, the reasons for this are several: the depletion of fields, the fall in oil and gas prices, as well as the decline in production, due to the frequent earthquakes, at the largest field in the EU - "Groningen";

- due to the growth of the economies of individual EU countries, the refusal of many thermal power plants from coal in favor of gas, as well as lower prices, the volume of gas consumption in the European Union, after several years of reduction $(2010-2014)$, are growing again;

- forecasts of experts on large-scale deliveries of LNG from the US in 2016-2018 (up to 50 million tons by 2020) were not confirmed, the maximum volume was 2.7 billion $\mathrm{m}^{3}$ by the end of 2018 ;

- in 2015 - 2018, PJSC "Gazprom" managed to increase the volume of natural gas supplies to the EU countries to record levels. At the end of 2018, the share of Russian gas in the market of the European Union amounted to more than $34 \%$, and there are objective prerequisites for its increase in the next 2-3 years;

- the successful implementation of the "Yamal-LNG" project allowed the Russian Federation to significantly increase the volume of liquefied natural gas supplies to the EU countries to 4,4 million tons by the end of 2018. And at the end of February 2019, Russia ranked first in LNG supplies to Europe - 1.41 million tons, ahead of Qatar - 1.33 million tons, the US -0.64 million tons and a number of other countries.

\section{ACKNOWLEDGMENTS}

The study was performed by the government task KSC RAS No 0226-2019-0028.

\section{REFERENCES}

[1] V. V. Elistratov, "Energy, environmental and socio-economic aspects in the energy supply of the Northern and Arctic territories of the Russian Federation" in The Ecological bulletin of Russia = Ekologicheskij vestnik Rossii, 2017, no. 11, pp. 30-35. (In Russ.).

[2] I Pivovarova, A Makhovikov, "Ecological regionalization methods of oil producing areas" in Journal of Ecological Engineering, 2017, no.18(1).

[3] European Statistics Database Eurostat URL https://ec.europa.eu/eurostat/data/database [accessed 10.06.2019].

[4] Statistical review of world energy June 2017 British Petroleum URL: https://www.bp.com/content/dam/bp-country/de_ch/PDF/bpstatistical-review-of-world-energy-2017-full-report.pdf [accessed: 09.06.2019].

[5] Dilaver Ö, Dilaver Z, Hunt LC. What drives natural gas consumption in Europe? Analysis and projections. Journal of Natural Gas Science and Engineering, 2014, no. 19, pp. 125-36.

[6] M.V. Ulchenko Features and methods of natural gas supply to the EU countries by Norway Fundamental research, 2015, no 10 (2). pp. 427-431. https://elibrary.ru/download/elibrary_24273208_99932382.pdf [accessed: 09.06.2019].

[7] Will Algeria be able to displace Russian gas EADaily: information agency URL: https://eadaily.com/ru/news/ 2017/05/17/ [accessed 25.05.2019].

[8] Total tripled gas extraction Designing gas supply URL: http://proektgaz.ru/news/ total_vtroe_uvelichila_svoju_gazodobychu_v_alzhire/2018-04-037198 [accessed 25.10.2018].

[9] Electronic guide The Norwegian Petroleum Directorate URL: https://www.npd.no/en/facts/publications/[accessed 25.10.2018]. 
[10] Federal state statistics service Rosstat http://www.gks.ru [accessed 10.06.2019]

[11] Results of the St. Petersburg international economic forum - 2019 Kommersant. URL: https://www.kommersant.ru/doc/3997633 [accessed 25.05.2019].

[12] Didenko, N.I., Skripnuk, D.F., Mirolyubova, O.V., Merkulov, V., Sevashkin, V., Samylovskaya, E. System of econometric equations of the world market of natural gas (2018) 2018-January, pp. 217-222.

[13] Tcvetkov P, Pritulyak D, Tananykhin D. Comparison of the MultiDirectional Delivery Efficiency of Low-Tonnage LNG and Pipeline Gas in Russia. In Journal of Physics: Conference Series 2018 Aug (Vol. 1072, No. 1, p. 012021). IOP Publishing.

[14] Kozmenko S, Tesla A, Fedoseev S 2018 Maritime economics of the Arctic: Legal regulation of environmental monitoring IOP Conf. Series: Earth and Environmental Science 180 (1) 012009

[15] Kozmenko S Yu, Masloboev V A, 2018 Formation of rational structure of the Arctic gas transportation system Economy and entrepreneurship 9 (98) 1279-1284

[16] Cherepovitsyn AE, Chanysheva AF. Oil and Gas Companies and States Organizational and Economic Mechanism of Interactions for Cross-Border Marine Oil and Gas Fields. Academy of Strategic Management Journal. 2017 Oct 2;16.

[17] S.A. Savelyev, M.V. Ulchenko M.V. Prospects for LNG supplies from the US to Europe. North and market: formation of economic order, 2016, no 3(50) pp. 55-62

[18] Wood DA. A review and outlook for the global LNG trade. Journal of Natural gas science and Engineeri, 2012, no 1(9) pp.16-27. 